\title{
The Ethically Conscious Flower Consumer: Understanding Fair Trade Cut Flower Purchase Behavior in Germany
}

\author{
Meike Rombach ${ }^{1, *(\mathbb{D}}$, David L. Dean ${ }^{2}\left(\mathbb{D}\right.$, Nicole J. Olynk Widmar ${ }^{3}{ }^{(\mathbb{D}}$ and Vera Bitsch ${ }^{4}(\mathbb{C}$ \\ 1 Department of Land Management and Systems, Lincoln University, Lincoln 7647, New Zealand \\ 2 Department of Agribusiness and Markets, Lincoln University, Lincoln 7647, New Zealand; \\ david.dean@lincoln.ac.nz \\ 3 Department of Agricultural Economics, Purdue University, West Lafayette, IN 47907, USA; \\ nwidmar@purdue.edu \\ 4 School of Management and School of Life Sciences, Chair of Economics of Horticulture and Landscaping, \\ Technical University of Munich, 85354 Freising, Germany; bitsch@tum.de \\ * Correspondence: meike.rombach@lincoln.ac.nz
}

\section{check for} updates

Citation: Rombach, M.; Dean, D.L.; Widmar, N.J.O.; Bitsch, V. The Ethically Conscious Flower Consumer: Understanding Fair Trade Cut Flower Purchase Behavior in Germany. Sustainability 2021, 13, 12133. https://doi.org/10.3390/ su132112133

Academic Editors: Jaywant Singh, Weisha Wang, Benedetta Crisafulli and Lester Johnson

Received: 6 October 2021

Accepted: 1 November 2021

Published: 3 November 2021

Publisher's Note: MDPI stays neutral with regard to jurisdictional claims in published maps and institutional affiliations.

Copyright: (c) 2021 by the authors. Licensee MDPI, Basel, Switzerland. This article is an open access article distributed under the terms and conditions of the Creative Commons Attribution (CC BY) license (https:/ / creativecommons.org/licenses/by/ $4.0 /)$.

\begin{abstract}
Fair trade flowers are an important niche product relevant to ethically conscious consumers. The study proposes a model that investigates key factors affecting the behavior of these cut flower consumers in Germany. The study serves to complement the existing studies dedicated to preferences for flower attributes and products, as well as consumers' willingness to pay. It builds on an online survey with a representative sample of 772 German cut-flower consumers. Partial least squares structural equation modelling shows that concern for the treatment of workers from countries with poor environmental and labor reputations, the breadth of fair trade cut flower information sources, and familiarity with the fair trade concept and its influence on flower production issues positively impact the relative importance that consumers dedicate to fair trade certification as a cut flower attribute. The same factors also positively impact fair trade cut flower buying behavior. Socio-demographic factors did not show any impact. The study concludes with best practice recommendations for retailers and horticultural marketers on how to address the needs and wants of ethically conscious consumers.
\end{abstract}

Keywords: cut flowers; ethical consumption; fair trade; flower retail; Germany; PLS-SEM

\section{Introduction}

In the past decade, the segment of ethically conscious consumers buying fair tradecertified horticultural food and non-food items such as coffee, bananas, chocolates and cut flowers has steadily increased in Germany [1-8]. This can be attributed to heightened consumer awareness, understanding of sustainable production and issues of environmental and social sustainability [6,9]. Given that the concept of fair trade is closely aligned with various United Nations Sustainable Development Goals (SDGs), including poverty alleviation (goal 1), gender equality (goal 5), decent work and economic growth (goal 8), responsible consumption and production (goal 12) and climate actions, many ethical conscious consumers are in favor of fair trade certified products $[10,11]$.

Ethical consumption refers to an individual's respect and concern for societal problems related to the environment, animal welfare, and human rights [12-14]. Ethical consumers tend to satisfy their needs and wants while simultaneously being mindful of how their consumption behaviors contribute to societal problems [15]. In response, they strive to avoid or boycott products that exploit or harm the environment or marginalized people [16,17]. Ethical products can be distinguished through labels of certification bodies such as Fair Trade International, which aim to identify, address, and overcome these societal problems. In the context of horticultural non-food production, the purchase of fair trade cut flowers might improve the working and living conditions of small-scale flower producers and reduce child labor in countries violating labor rights, such as Kenya, Ethiopia and Ecuador [6]. 
The majority share of cut flowers sold in Germany are imported from Kenya [18,19] and include roses, carnations, alstroemeria, lisianthus, statice and cut foliage [20]. The trade value of Kenyan cut flowers was $€ 45,364,400$ in 2018, much larger than other countries [21].

The Kenyan cut flower industry continues to grow, operating in state of the art greenhouses, and flower certification bodies have been working to document and counteract issues such as land grabbing [22], long working hours, poor treatment and payment of labor, and other injustices including sexual harassment [23-26]. In addition, certification bodies enforce production standards and good agricultural practices when it comes to the use of agrochemicals and water management [27-30].

From this background, fair trade cut flowers can be considered a manifestation of ethical consumption in Germany. Market data shows that the market share for fair trade cut flowers is growing. Revenue from fair trade cut flowers sold in Germany has increased from $€ 29.69$ million in 2011 to $€ 167$ million in 2020 [31]. The value for 2020 represents a sales volume of 507 million stems [32]. It is estimated that the average German consumer spends $€ 39$ per capita annually for cut flowers [18], which includes both ordinary and fair trade cut flowers.

From a consumer perspective, fair trade cut flowers in Germany have yet to reach mass appeal, although they are attractive to ethically conscious buyers as a consumer segment $[6,33]$. As such, fair trade cut flowers are considered a niche product. This niche product has been discussed in the he academic literature, but has not been extensively researched [6,34]. Previous studies have examined cut flower preferences for sustainable labels and have found fair trade certified products to be more appealing to consumers than organic or other sustainable certification schemes $[6,34,35]$. Other recent flower studies have explored consumer preferences for flower attributes, but they have primarily examined willingness to pay for floral products [5,35] and have focused on differences between physical and online shops $[5,36]$. Accordingly, previous studies have been dedicated to understanding consumer behavior, but have not yet widely covered attitudinal factors that affect the buying decision [34]. For this reason, the present study aims to bridge this research gap and is dedicated to exploring key factors that determine flower buying behavior. Given that ethically conscious consumers show strong interest in production processes, retailer reputation and product attributes, and they also hold strong moral values and inform themselves about the product they buy, these aspects form the basis for the key factors investigated in the present study.

\section{Theoretical Background}

Given the presence of only a few consumer studies dedicated to fair trade cut flowers in Germany $[5,6,34,35]$, this literature review borrows from the wider research on horticultural and agricultural food products. It is expected that the key factors impacting buying behaviour will be similar, given the perishability and limited shelf life of both food and flowers. The literature review focuses on issues like concern for worker treatment, concern for environmental practices, information search practices, socio-demographic information, product familiarity and preferences for particular flower attributes, as these key factors are considered essential to understanding buying behaviour.

\subsection{Concern for Floriculture Worker Treatment and Environment Practices in the Flowers Country of Origin}

Singh (2013) discusses the behaviour of flower consumers living in wealthy countries where labour rights are respected and where political actors and media reports voice concern about the negative externalities commonly associated with cut flower production in the flowers' country of origin ( $\mathrm{CoO})$ [37]. These include child labour, health risks, soil and water pollution, sexual exploitation of women, and unfair distribution of water resources. The study highlights the adverse effects of boycotting flowers from CoOs with poor environmental and labour reputations, like those in Latin America and Africa, as banning and boycotting these products leads to adverse effects such as job losses, subsequent destitution, and starvation [37]. Also, Werren (2015) addresses Australian consumers' 
concerns about labour treatment and payment in global cut flower chains [38]. Given that cut flowers from CoOs with poor environmental and labour reputations are imported to Australia, and Australian consumers favour sustainable practices and social responsibility, businesses in the Australian floricultural industry need to be more attentive to their product assortment and advocate country-of-origin labelling and product certification [38]. Both studies corroborate the findings of Holt and Watson (2008) who investigated local versus international sourcing of food and flowers in retailers [39]. Their study outlines the complexity of global value chains and emphasizes growing consumer concern towards the production practices and dependencies occurring in production. The authors called for research on certification and social/environmental impacts in order to assure consumers of the legitimacy of the products they purchase [39]. Based on these findings, German consumers that favour sustainable practices and social responsibility will be more likely to favour the tenets of fair trade as a flower attribute and prefer fair trade cut flowers. Thus, the following hypotheses are proposed:

Hypothesis 1 (H1). German consumers who are more concerned about worker treatment in CoOs with poor environmental and labour reputations will place more importance on fair trade as a cut flower attribute.

Hypothesis 2 (H2). German consumers who are more concerned about environmental practices in CoOs with poor environmental and labour reputations will place more importance on fair trade as a cut flower attribute.

\subsection{The Breadth of Information Sources Used to Obtain Information about Fair Trade Cut Flowers}

Whether and how German consumers search for information about fair trade cut flowers has yet to be explored. However, Ambrožová and Částek (2013) investigated information practices and purchase behaviour for fair trade food products in the Czech Republic. Their results show that consumers use a variety of sources to inform themselves. They obtain information from resources provided by the certification body itself, from friends, from shop assistants or from the internet. Some consumers do not use any information sources [40].

Further evidence of the information practices of consumers interested in ethical consumption can be deduced from Gross and Roosen (2020). Their study investigated how German consumers perceive the trustworthiness and informativeness of different information sources reporting on agricultural production practices [41]. The results of the panel regression analysis showed that information from the government, in particular from the Ministry of Agriculture was perceived as more trustworthy and informative than information shared by the Federation of German Consumer Associations. German consumers perceive information without an indication of source as the least trustworthy [41]. Their findings contrast with earlier US studies reporting that consumer organizations ranked higher in their trustworthiness than governmental organizations [42].

McKendree et al. (2014) studied the agriculture and information practices of US consumers. The study found that most consumers do not seek out information about societal issues related to food production because it leads to unpleasant feelings and discomfort [43]. However, the consumers who were seeking information relied on nonprofit or activist organizations, government agencies, research institutions and universities, agricultural industry groups, and social media [43].

In conclusion, fair trade and other ethical consumer studies show that information practices, including consumer use and perceived trustworthiness of sources, are diverse when it comes to ethical issues in food production. In the absence of a clear direction for identifying single sources of trustworthy information, consumers who draw from a variety of different sources are likely to find compelling fair trade information. Adapting this information to the cut flower context, the following hypotheses are proposed: 
Hypothesis 3 (H3). German cut flower consumers who use a broader range of sources for their fair trade flower information are likely to place more importance on fair trade as a cut flower attribute.

Hypothesis 4 (H4). German cut flower consumers who use a broader range of sources for their fair trade flower information are more likely to exhibit fair trade cut flower buying behaviour.

\subsection{Familiarity with Fair Trade Cut Flower Production}

Consumer familiarity with the concept of fair trade is widely studied. De Pelsmacker et al. (2006) studied fair trade coffee in Belgium in two consumer groups, namely "Oxfam store visitors" and "regular consumers" [44]. Their results showed that both groups of consumers had at least a basic understanding of the fair trade concept. While regular consumers were aware of the social impact of the scheme, they still associate it more with the environment. Oxfam store visitors were aware of the impact and contribution of the scheme, but, surprisingly, this knowledge was not necessarily translated into positive attitudes toward fair trade products [44]. These findings confirm those of an early study emphasizing the problem of translating fair trade principles into consumer purchasing behaviour [45].

More recent studies emphasize good consumer knowledge or familiarity with fair trade and ethical products [46-49]. However, there is concept confusion amongst consumers due to an overwhelming presence of labels [50-52]. The co-existence of credible labels from certification bodies verifying credence product attributes such as fair trade, and other pretentious or meaningless labels, leads to consumer bias, confusion, irritation and resignation [7].

Ethically conscious German flower consumers are likely to face this problem, as there are various flower labels indicating fairness in flower trading on the German market. One is the traditional fair trade label, dedicated to improving the livelihood of farmers in countries with poor environmental and labour reputations and campaigning against child labour. This label is somewhat recognized by flower consumers $[53,54]$. Other flower labels include the MPS certification label and the green certificate. Both labels are dedicated to certifying environmentally produced ornamental plants and cut flowers and include a social component which addresses human labour [6,34,55].

While the green certificate is dedicated to the development and training of labour in the German horticultural industry [55], the MPS scheme follows the same goals as fair trade. Various flower farms in Kenya, Tanzania, Sri Lanka, and India, have been awarded with the certification [24]. Consumer familiarity with these labels remains so far unknown. Furthermore, it is yet to be explored in more detail how familiar German consumers are with the concept of fair trade in a non-food context such as cut flowers. Accordingly, the following hypotheses are proposed:

Hypothesis 5 (H5). German cut flower consumers with more familiarity with fair trade cut flower production are likely to place more importance on fair trade as a cut flower attribute.

Hypothesis 6 (H6). German cut flower consumers with more familiarity with fair trade cut flower production are more likely to exhibit fair trade cut flower buying behaviour.

\subsection{The Relative Importance of Fair Trade as Cut Flower Attribute}

Prior research on food and cut flower attributes emphasized several intrinsic and extrinsic product attributes that are important to consumers [6,34,56,57]. Intrinsic attributes are inherent to a product, for instance, appearance, texture, scent and freshness [57]. Extrinsic product attributes relate to the commercial and production aspects of the product and include price, packaging, and Fair trade certification [2]. Intrinsic and extrinsic attributes both provide cues to consumers which are used to evaluate food or flowers and decide which product to purchase. Many horticultural product studies focused exclusively on one attribute $[35,57]$. However, when consumers make purchasing decisions, they choose 
from different product alternatives, each with different bundles of attributes. This enforces decision making and trade-offs [56].

Auger et al. (2007) used a best-worst approach to study the relative importance given by consumers to ethical issues across Germany, Spain, Turkey, USA, India and Korea [58]. The study found that regardless of an individual's nationality, labour and human rights were consistently chosen as "more important" than other ethical issues. This is an indicator of the importance of fair trade-certified products in the European, US and Asian consumer markets [58].

Specifically, in a cut flower context, Rombach et al. (2018) investigated German consumer preferences for cut flower attributes in a bundle format using a best-worst approach and a latent class analysis [53]. Their results showed that that intrinsic flower attributes, particularly appearance, freshness and scent, were more important to German consumers than the extrinsic attributes studied, namely, price, country of origin and fair trade certification. The latent class analysis determined four consumer segments that desired either budget, luxury, or ethical flowers or more information about flowers [53].

Berki-Kiss and Menrad (2019) explored the preferences of German consumers for certified cut flowers using a choice-based conjoint experiment with roses and included sustainability certification, country of origin, packaging, smell, and flower head size [6]. Their latent class analysis revealed consumer heterogeneity with around two-thirds of the over 1000 respondents strongly in favour of sustainability-certified flowers. Further, fair trade-certified roses received an overall positive assessment in contrast to organically certified ones. In addition, paper or no packaging, pleasant scent and uniform appearance of the flower heads received positive consumer evaluations [6]. In summary, it can be deduced that the intrinsic attributes of cut flowers are the most important for flower consumers, but certain consumer segments find fair trade-certified flowers appealing. It is hypothesized that:

Hypothesis 7 (H7). German cut flower consumers who place more importance on fair trade as a cut flower attribute are more likely to exhibit fair trade cut flower buying behaviour.

\subsection{Socio-Demographic Information}

Numerous studies dedicated to the socio-demographic backgrounds of ethical consumers included consumers having an interest and buying fair trade products. The body of literature is, however, not conclusive [4,59-61]. While older studies have identified people with higher education, higher income, and being female as relevant socio-demographic factors impacting ethical food purchasing behaviour [47], more recent studies have found that socio-demographic factors are not good predictors of ethical food purchasing behaviour $[8,34,53,54]$. In a cut flower context, these diverse findings are confirmed by Michaud et al. (2013), Rombach et al. (2018) and Berki-Kiss and Menrad (2019) [6,53,62]. For food and flowers, experiential and attitudinal factors appear to be more relevant influencers of ethical consumption behaviour, but socio-demographic variables have been included in this research as a form of statistical control. Due to the absence of consensus in the body of the literature, the following hypotheses addressing socio-demographic factors are proposed:

Hypothesis 8a (H8a). German cut flower consumers that are older are more likely to exhibit fair trade cut flower buying behaviour.

Hypothesis $\mathbf{8 b} \mathbf{( H 8 b ) . ~ G e r m a n ~ c u t ~ f l o w e r ~ c o n s u m e r s ~ w i t h ~ h i g h e r ~ i n c o m e ~ a r e ~ m o r e ~ l i k e l y ~ t o ~ e x h i b i t ~}$ fair trade cut flower buying behaviour.

Hypothesis 8c (H8c). German cut flower consumers with higher education are more likely to exhibit fair trade cut flower buying behaviour. 


\subsection{Conceptual Model}

A conceptual model is proposed (Figure 1) suggesting that fair trade cut flower purchasing behaviour is the result of a combination of factors. Concern for cut flower production practices and familiarity with fair trade cut flowers and information practices are used to understand preferences for fair trade as a cut flower attribute that ultimately influences buying behaviour. Socio-demographic factors, including age, income, and education could provide an alternative explanation for cut flower buying behaviour. Overall, testing the model will clarify how attitudinal and experiential factors contribute to cut flower buying behaviour, and whether socio-demographic factors have a role to play.

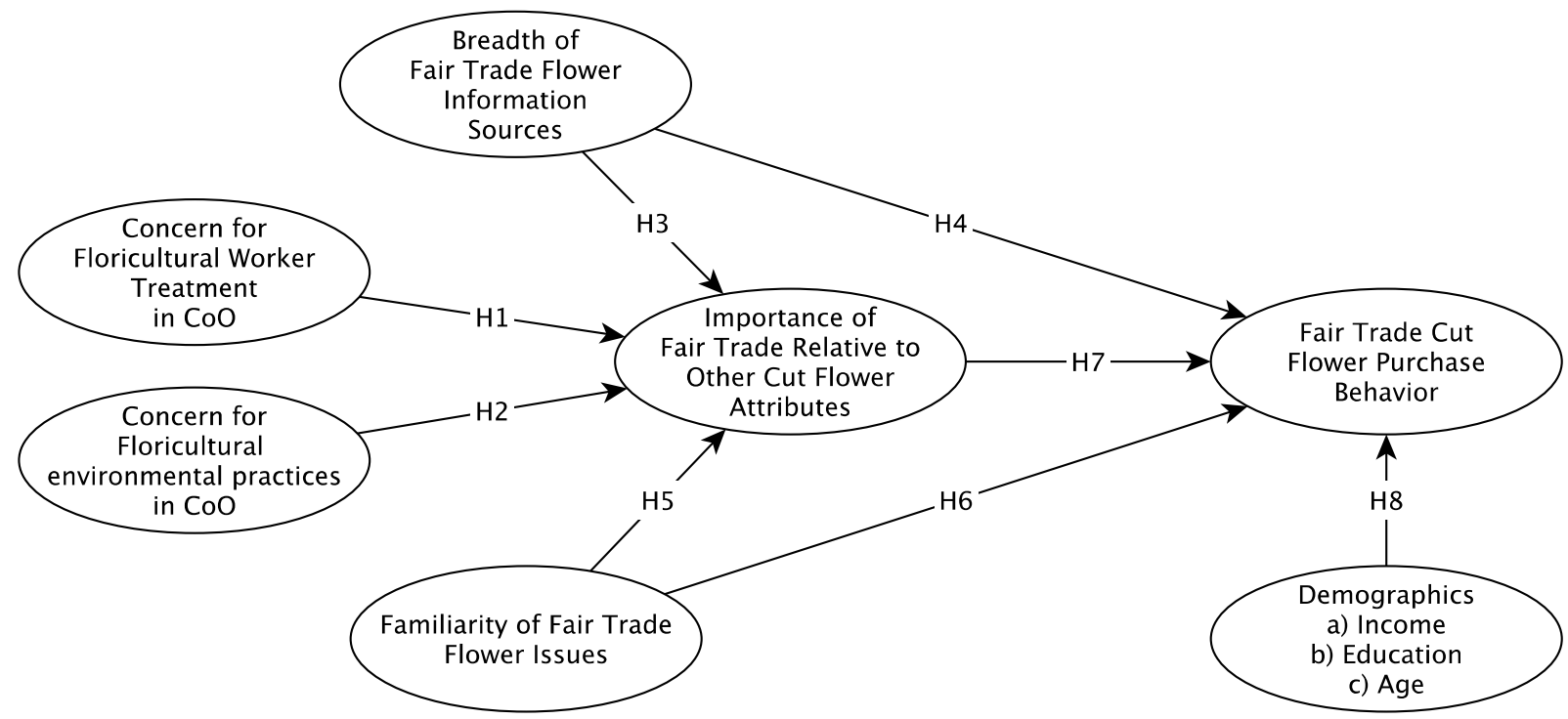

Hypotheses:

$\mathrm{H} 1$ : Concern for Floricultural Worker Treatment in $\mathrm{CoO}->$ Importance of Fairtrade Relative to other Cut Flower Attributes

$\mathrm{H} 2$ : Concern for Floricultural Environmental Practices in $\mathrm{CoO}->$ Importance of Fair Trade Relative to other Cut Flower Attributes

H3: Breadth of Fair Trade Flower Information Sources $->$ Importance of Fair Trade Relative to other Cut Flower Attributes

H4: Breadth of Fair Trade Flower Information Sources -> Fair Trade Cut Flower Purchase Behaviour

H5: Familiarity of Fair Trade Flower Issues -> Importance of Fair Trade Relative to other Cut Flower Attributes

H6: Familiarity of Fair Trade Flower Issues -> Fair Trade Cut Flower Purchase Behaviour

H7: Importance of Fair Trade Relative to other Cut Flower Attributes -> Fair Trade Cut Flower Purchase Behaviour

H8a: Income -> Fair Trade Cut Flower Purchase Behaviour

H8b: Education -> Fair Trade Cut Flower Purchase Behaviour

H8c: Age $->$ Fair Trade Cut Flower Purchase Behaviour

Figure 1. Conceptual framework.

\section{Material and Methods}

\subsection{Survey Instrument and Data Collection}

Data were collected from a sample of German residents targeted to be representative of the German population in terms of age, gender, and monthly net household income following the most recent German census (2011) [63]. A questionnaire was developed for an online survey administered in March 2016. The survey was administered through the survey software Qualtrics and distributed via email by Lightspeed GMI, an opt in-panel provider. Respondents had to be German residents and 18 years old to participate. The data collection resulted in 978 completed responses, of which 772 (420 females and 352 males) were used for this analysis, given that those respondents indicated that they had purchased cut flowers in the last 12 months.

The necessary survey sample size (S) of a minimum of 385 respondents was calculated as $\mathrm{s}=\mathrm{x} /[1+(\mathrm{x} / \mathrm{P})]$. In this equation, $\mathrm{P}$ is the total size of the population (82.18 million people) from which the sample is drawn and $x=Z \times Z\{[F \times(1-F)] /(D \times D)\}$, in which $Z$ is the area under the normal curve corresponding to the desired confidence level (1.96, per a $95 \%$ confidence interval), $\mathrm{F}$ is the frequency of the factor in the study $(0.5)$, and $\mathrm{D}$ is 
the maximum acceptable difference between the sample and population means (0.05). Consequently, the sample of 772 flower buyers used for this analysis was sufficient.

The questionnaire was written in the German language and consisted of various sections with fixed response questions where respondents were asked to indicate their interest in cut flowers, cut flower attributes and fair trade cut flowers, as well as their concern for floricultural production practices in countries with poor environmental and labour reputations and their familiarity with the concept of fair trade.

\subsection{Construct Measurement}

Constructs were measured using a variety of methods. Concern for floricultural workers' treatment (2 items) and environmental practices ( 3 items) in countries with poor environmental and labour reputations were measured on 7-point Likert scales from "not concerned" to "extremely concerned." The breadth of fair trade flower information sources and familiarity with fair trade flower issues were measured with index scores. For the breadth of fair trade flower information sources, respondents were asked to indicate whether they had obtained information from nine information sources provided. Sources included flower shops, social media, documentaries, promotions/advertisements, fairs/exhibitions, newspapers, and the websites of the Federal Ministry of Food and Agriculture, Fairtrade Germany, and the Association of German Florists.

For familiarity with fair trade flower issues, respondents were asked to indicate whether they were familiar with the ten fair trade issues provided: fair prices for producers, pre-financing for producers, support for small scale farms, price stabilization, health and education investments, working condition regulations, environmental sustainability regulations, production chain transparency, long-term producer relationships, and requirements of organic production. The importance of fair trade relative to other cut flower attributes was measured using best-worst scaling, pitted against six other product attributes: price, country of origin, appearance, packaging, scent, and freshness guarantee. Finally, the remaining constructs were measured with fixed responses (see Table 1).

Table 1. Sample Description.

\begin{tabular}{ccccc}
\hline Scale & Freq & $\%$ & Median & StDev \\
\hline Age & & & & \\
\hline 18-29 years & 132 & 17.1 & & \\
30-49 years & 275 & 35.6 & & \\
50-64 years & 187 & 24.2 & & \\
65 years and above & 178 & 23.1 & \\
Total & 772 & 100 & \\
Education & & & \\
\hline No professional certificate & 23 & 3 & \\
Vocational Degree & 317 & 41.1 & \\
Technical Degree & 82 & 10.6 & \\
Professional Academy & 48 & 6.2 & \\
Applied Science Degree & 108 & 14 & \\
University Degree & 166 & 21.5 & \\
Doctoral degree & 15 & 1.9 & \\
Other & 13 & 1.7 & \\
Total & 772 & 100 & \\
\hline
\end{tabular}


Table 1. Cont.

\begin{tabular}{ccccc}
\hline Scale & Freq & $\%$ & Median & StDev \\
\hline Household Monthly Income & 42 & & & \\
Less than $900 €$ & 68 & 5.4 & \\
900 to $1299 €$ & 48 & 8.8 & \\
1300 to $1499 €$ & 126 & 6.2 & \\
1500 to $1999 €$ & 131 & 16.3 & \\
2000 to $2599 €$ & 161 & 17 & \\
2600 to $3599 €$ & 132 & 17.1 & \\
3600 to $4999 €$ & 64 & 8.3 & \\
5000 or more $€$ & 772 & 100 & \\
Total & & & \\
\hline
\end{tabular}

\subsection{Data Analysis}

Descriptive statistical analyses and partial least squares structural equation modelling (PLS-SEM) were used to analyze the data. The latter analysis method is particularly suitable for investigating complex causal dependencies of latent constructs in explorative models, and coefficient paths where data is not normally distributed. PLS-SEM combines path analysis, principal component analysis and regression analysis [64,65], and was developed by Wold [66]. The software packages SPSS and SmartPLS were used to examine the research model and test the proposed hypotheses.

The analysis was carried out following a two-step approach, whereby the first step consisted of checking reliability and validity via measurement model functions. Indicator reliability is based on indicator loadings, which should be greater than 0.4 . The average variance extract $(\mathrm{AVE}>0.5)$, construct reliability (Cronbach's Alpha $>0.6$ ) and composite reliability $(C R>0.6)$, were used to test the convergence criterion $[65,67]$.

The Fornell-Larcker criterion and cross-loadings determine discriminant validity. When testing discriminant validity by checking cross-loading, all items should have a higher correlation with their assigned factor than with other factors. The Fornell-Larcker criterion is fulfilled if the square root of each construct's AVE is greater than the correlation with other constructs $[65,67,68]$. Following Henseler et al. (2015), the heterotrait-monotrait ratio of the correlations criterion (HTMT) is used to confirm discriminant validity, with a threshold value of 0.9 [69]. Finally, multicollinearity was checked with the variance inflation factor (VIF), which is recommended to be under 5 .

The second step is the structural fit of the model. To evaluate model quality, the model fit is reported and the explanatory power is evaluated [65]. Hair et al. (2017) caution the interpretability of the model fit indices in SEM-PLS [65], but convention suggests that the goodness of fit (GoF), normed fit index (NFI) be reported, and the GoF and NFI scores vary from 0 to 1 , where closer to 1 is considered a better fit.

The standardized root mean square residual (SRMR) is also reported, and a value of less than 0.08 is considered acceptable. Another measure is the explanatory power of the model, evaluated as the individual and average variance explained $\left(R^{2}\right)$ of the dependent variables, classified as small $\left(R^{2}>0.1\right)$, as medium $\left(R^{2}>0.3\right)$ and large $\left(R^{2}>0.5\right)$ as specified by Cohen (1992) [67]. When an adequate model structure is established, the hypothesised paths are tested for significance.

\section{Results}

Tables 1 and 2 show the descriptive statistics for the demographics and other constructs measured with index or single item scores, respectively. 
Table 2. Index/Single Item Measures.

\begin{tabular}{lcccc}
\hline Scale & Mean & Min & Max & \\
\hline $\begin{array}{c}\text { Breadth of Fair Trade Flower Information Sources } \\
\text { (Sum of reported use of 10 offered sources) }\end{array}$ & 9 & 1.43 \\
\hline Number of Sources & 1.31 & 0 & 2.28 \\
\hline \multicolumn{5}{c}{ Familiarity Fair Trade Flower Issues } \\
(Sum of reported familiarity of 10 offered issues) & 10 \\
\hline Number of Issues & 2.25 & 0 & 1.83 \\
\hline
\end{tabular}

\subsection{Measurement Model}

Table 3 shows that while the Cronbach Alpha of concern for floricultural worker treatment in CoOs with poor environmental and labour reputations is just below the recommended minimum threshold, the composite reliability indicators of both multiple item measures have values greater than 0.7 and the average variance extracted (AVE) have values greater than 0.5. Further, the factor loadings of all items are more than 0.6. Overall, it was determined that the requirements of construct reliability and validity were satisfied [57].

Table 3. Scale Loadings, Reliabilities, and Convergent Validity.

\begin{tabular}{ccc}
\hline Scales and Items & Factor Loadings & $\begin{array}{c}\text { Cronbach's } \\
\text { Alpha }\end{array}$ \\
\hline Concern for Floricultural Worker Treatment in CoO & $\begin{array}{c}\text { Composite } \\
\text { Reliability }\end{array}$ & 0.675 \\
\hline $\begin{array}{c}\text { 41.4 Payment of floricultural workers in CoO concerns me. } \\
\text { 42.3 Floricultural working conditions in CoO concerns me. }\end{array}$ & 0.843 \\
\hline Concern for Floricultural Environmental Practices in CoO & 0.892 & 0.753 \\
\hline 41.1 Floricultural water use in CoO concerns me. & 0.746 \\
41.2 Floricultural plant protection practices in CoO concerns me. & 0.945 & 0.911 \\
41.3 Floricultural fertilizer practices in CoO concerns me. & 0.937 & 0.776 \\
\hline
\end{tabular}

Table 4 shows that the criteria for discriminant validity were satisfied, with crossloadings less than the diagonal values in the Fornell-Larcker criterion, and the HTMT ratios below 0.9. The average VIF value (between constructs) was calculated (1.296), and was below the recommended threshold of 5 .

Table 4. Discriminant Validity.

\begin{tabular}{|c|c|c|c|c|c|c|}
\hline Fornell-Larcker Criterion & $\begin{array}{l}\text { Breadth of } \\
\text { Fair Trade } \\
\text { Flower } \\
\text { Information } \\
\text { Sources }\end{array}$ & $\begin{array}{l}\text { Concern for } \\
\text { Floricultural } \\
\text { Environmen- } \\
\text { tal Practices } \\
\text { in CoO }\end{array}$ & $\begin{array}{l}\text { Concern for } \\
\text { Floricultural } \\
\text { Worker } \\
\text { Treatment in } \\
\text { CoO }\end{array}$ & $\begin{array}{l}\text { Fair Trade } \\
\text { Cut Flower } \\
\text { Purchase } \\
\text { Behaviour }\end{array}$ & $\begin{array}{c}\text { Familiarity } \\
\text { Fair Trade } \\
\text { Flower } \\
\text { Issues }\end{array}$ & $\begin{array}{c}\text { Importance } \\
\text { of Fair Trade } \\
\text { Relative to } \\
\text { Other Cut } \\
\text { Flower } \\
\text { Attributes }\end{array}$ \\
\hline $\begin{array}{l}\text { (1) Breadth of Fair Trade Flower } \\
\text { Information Sources }\end{array}$ & 1 & & & & & \\
\hline $\begin{array}{c}\text { Concern for Floricultural Environmental } \\
\text { Practices in } \mathrm{CoO}\end{array}$ & 0.104 & 0.881 & & & & \\
\hline $\begin{array}{l}\text { Concern for Floricultural Worker } \\
\text { Treatment in } \mathrm{CoO}\end{array}$ & 0.079 & 0.63 & 0.868 & & & \\
\hline Fair Trade Cut Flower Purchase Behaviour & 0.384 & 0.064 & 0.066 & 1 & & \\
\hline Familiarity Fair Trade Flower Issues & 0.486 & 0.19 & 0.129 & 0.308 & 1 & \\
\hline $\begin{array}{l}\text { Importance of Fair Trade Relative to other } \\
\text { Cut Flower Attributes }\end{array}$ & 0.2 & 0.169 & 0.171 & 0.408 & 0.179 & 1 \\
\hline
\end{tabular}


Table 4. Cont.

\begin{tabular}{|c|c|c|c|c|c|c|}
\hline Fornell-Larcker Criterion & $\begin{array}{l}\text { Breadth of } \\
\text { Fair Trade } \\
\text { Flower } \\
\text { Information } \\
\text { Sources }\end{array}$ & $\begin{array}{l}\text { Concern for } \\
\text { Floricultural } \\
\text { Environmen- } \\
\text { tal Practices } \\
\text { in CoO }\end{array}$ & $\begin{array}{l}\text { Concern for } \\
\text { Floricultural } \\
\text { Worker } \\
\text { Treatment in } \\
\text { CoO }\end{array}$ & $\begin{array}{l}\text { Fair Trade } \\
\text { Cut Flower } \\
\text { Purchase } \\
\text { Behaviour }\end{array}$ & $\begin{array}{c}\text { Familiarity } \\
\text { Fair Trade } \\
\text { Flower } \\
\text { Issues }\end{array}$ & $\begin{array}{c}\text { Importance } \\
\text { of Fair Trade } \\
\text { Relative to } \\
\text { Other Cut } \\
\text { Flower } \\
\text { Attributes }\end{array}$ \\
\hline \multicolumn{7}{|l|}{ Heterotrait-Monotrait Ratio } \\
\hline $\begin{array}{c}\text { Concern for Floricultural Environmental } \\
\text { Practices in } \mathrm{CoO}\end{array}$ & 0.111 & & & & & \\
\hline $\begin{array}{l}\text { Concern for Floricultural Worker } \\
\text { Treatment in } \mathrm{CoO}\end{array}$ & 0.094 & 0.842 & & & & \\
\hline Fair Trade Cut Flower Purchase Behaviour & 0.384 & 0.064 & 0.077 & & & \\
\hline Familiarity Fair Trade Flower Issues & 0.486 & 0.208 & 0.155 & 0.308 & & \\
\hline $\begin{array}{l}\text { Importance of Fair Trade Relative to other } \\
\text { Cut Flower Attributes }\end{array}$ & 0.2 & 0.18 & 0.207 & 0.408 & 0.179 & \\
\hline
\end{tabular}

\subsection{Structural Model}

The proposed structural model was tested, resulting in a GoF of 0.418 , an NFI of 0.831 and a SRMR of 0.046 (less than recommended maximum of 0.08), indicating adequate model fit. In terms of explanatory power, the explained variance $\left(R^{2}\right)$ of importance of fair trade relative to other cut flower attributes was 0.074 ; significant $(p<0.01)$ but below Cohen (1992)'s weak target. The $\mathrm{R}^{2}$ of fair trade cut flower purchasing behaviour was 0.276 , which was significant $(p<0.01)$ and between the weak and medium strength targets. Overall, the structural tests of the proposed model were satisfied, indicating that the hypothesis testing was appropriate.

Table 5 and Figure 2 show the results of the hypothesis testing. Concern for floricultural worker treatment in $\mathrm{CoOs}$ with poor environmental and labour reputations, breadth of fair trade flower sources, and familiarity with fair trade flower issues significantly $(p<0.05)$ influenced the importance of fair trade as a cut flower attribute, but floricultural environmental practices was not significantly influential. Thus, $\mathrm{H} 1, \mathrm{H} 3$, and $\mathrm{H} 5$ are supported, but no support was found for H2. In terms of cut flower purchase behaviour, breadth of fair trade flower information sources, familiarity with fair trade flower issues, and importance of fair trade as a cut flower attribute were all influential $(p<0.05)$, but demographics were not found to be influential. Thus, $\mathrm{H} 4, \mathrm{H} 6$, and $\mathrm{H} 7$ found support, but H8 did not.

Table 5. Path Coefficients.

\begin{tabular}{|c|c|c|c|}
\hline Hypothesised Relationship & Coefficient & T Stat & $p$ Value \\
\hline $\begin{array}{c}\text { H1: Concern for Floricultural Worker Treatment in } \mathrm{CoO}->\text { Importance of Fair } \\
\text { trade Relative to other Cut Flower Attributes }\end{array}$ & 0.102 & 2.426 & 0.015 \\
\hline $\begin{array}{c}\mathrm{H} 2 \text { : Concern for Floricultural Environmental Practices in } \mathrm{CoO}->\text { Importance of } \\
\text { Fair trade Relative to other Cut Flower Attributes }\end{array}$ & 0.074 & 1.869 & 0.062 \\
\hline $\begin{array}{c}\text { H3: Breadth of Fair trade Flower Information Sources -> Importance of Fair } \\
\text { trade Relative to other Cut Flower Attributes }\end{array}$ & 0.144 & 3.791 & 0.000 \\
\hline $\begin{array}{l}\text { H4: Breadth of Fair trade Flower Information Sources -> Fair trade Cut Flower } \\
\text { Purchase Behaviour }\end{array}$ & 0.257 & 6.679 & 0.000 \\
\hline $\begin{array}{l}\text { H5: Familiarity of Fair trade Flower Issues -> Importance of Fair trade Relative } \\
\text { to other Cut Flower Attributes }\end{array}$ & 0.082 & 1.981 & 0.048 \\
\hline $\begin{array}{l}\text { H6: Familiarity of Fair trade Flower Issues -> Fair trade Cut Flower } \\
\text { Purchase Behaviour }\end{array}$ & 0.122 & 3.203 & 0.001 \\
\hline $\begin{array}{c}\text { H7: Importance of Fair trade Relative to other Cut Flower Attributes -> Fair } \\
\text { trade Cut Flower Purchase Behaviour }\end{array}$ & 0.336 & 11.239 & 0.000 \\
\hline
\end{tabular}


Table 5. Cont.

\begin{tabular}{cccc}
\hline Hypothesised Relationship & Coefficient & T Stat & $p$ Value \\
\hline H8a: Income $->$ Fair trade Cut Flower Purchase Behaviour & 0.051 & 1.623 & 0.105 \\
\hline H8b: Education $->$ Fair trade Cut Flower Purchase Behaviour & -0.016 & 0.469 & 0.639 \\
\hline H8c: Age $->$ Fair trade Cut Flower Purchase Behaviour & 0.010 & 0.307 & 0.759 \\
\hline Bold $=p<0.05$ & & \\
\hline
\end{tabular}

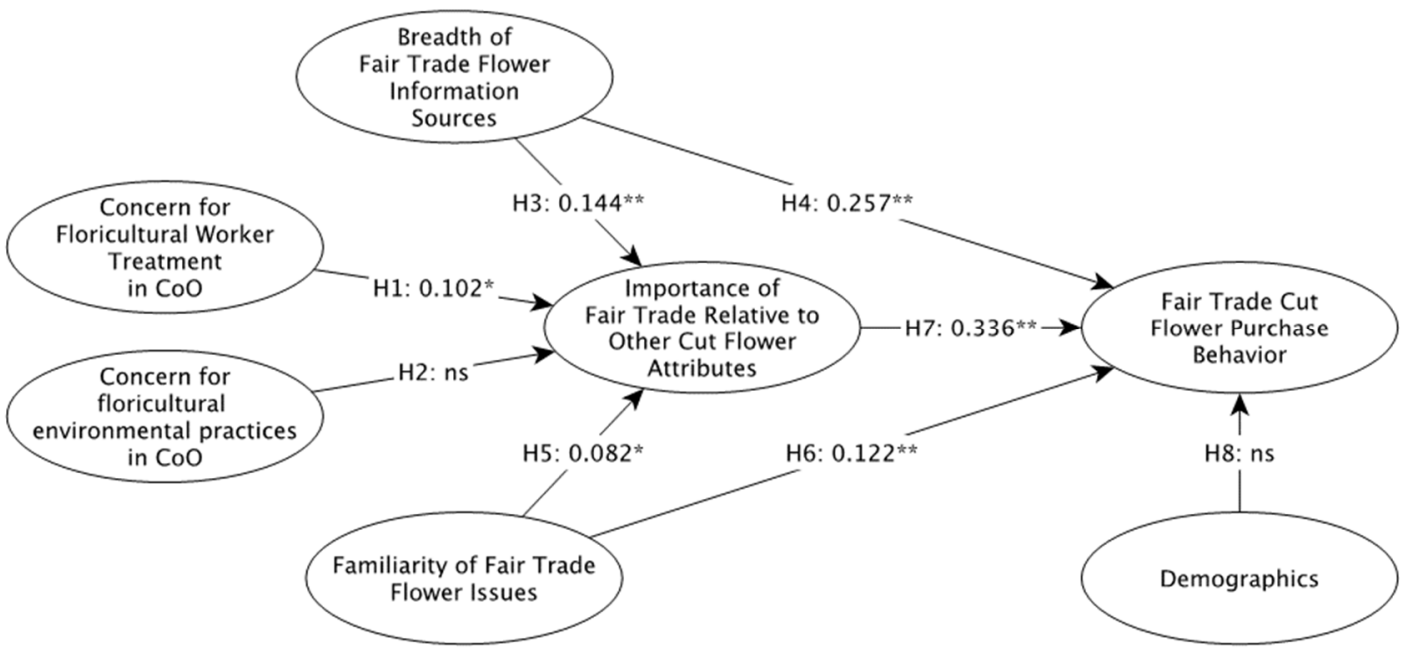

Figure 2. Model with relationship values. ${ }^{*}$ Significant at $p<0.05$; ${ }^{* *}$ significant at $p<0.01$; ns: not significant.

\section{Discussion}

This study seeks to contribute to the understanding of the factors explaining German consumer fair trade cut flower buying behavior. Overall, the proposed fair trade cut flower buying behavior model was found to have an adequate fit and explanatory power.

These results emphasize that the importance of concern for the treatment of workers in $\mathrm{CoOs}$ with poor environmental and labor reputations, the breadth of fair trade cut flower information sources, and familiarity with the fair trade concept and their influence on production issues, positively impacted the relative importance consumers assign to fair trade certification as a cut flower attribute. The same factors also have positive impacts on buying behavior, but socio-demographic factors were not found to have an impact.

The model confirms previous findings that socio-demographic backgrounds of consumers are not as relevant as earlier studies on fair trade and ethical consumption have reported. Consistent with Andorf and Liebe (2012) and Pedrini and Ferri (2014), this study found that attitudes, experience, and product familiarity are important drivers of purchasing behavior for ethically conscious consumers [4,61]. Perhaps cut flowers are viewed by consumers as a trending product $[52,70,71]$, and fair trade flower buying behavior is part of a lifestyle [6].

It is noteworthy that, for German consumers, concern for labor treatment and concern for the environmental practices in cut flower production did not have the same impact on fair trade cut flower attitudes. The hypothesized influence of concern for labor treatment was supported, whereas the hypothesized influence of environmental concerns was not, but similar findings exist in the literature [6,57]. Auger et al. (2007) indicate that for ethically conscious consumers, concern for human rights has a higher priority than concern for the environment [58], and this finding was confirmed by Berki-Kiss and Menrad (2019). They found that German consumers tend to favor fair trade roses over organic roses, demonstrating that human rights seem to edge out environmental concerns for ethically conscious consumers [6]. 
Product choices are often the result of an information search, the results of which vary in the types of information sources, their credibility, and consumers' perception and use of these sources [46]. This variability was also found among German fair trade cut flower consumers. Flower familiarity is usually the result of consumers' product-related experiences, based on their frequency of purchasing and handling cut flowers [72]. The findings of familiarity as an impacting factor toward the attribute preferences and buying behavior of ethically conscious German flower consumers are well in line with social judgement theory and ethical acceptability. Social judgement theory postulates that the extent of product familiarity tends to influence the acceptance of products [73]. Strong familiarity can lead to a high level of product discrimination. In a flower context, this means that ethically conscious German flower consumers may consider a narrower range of acceptable flower products and their respective attributes. Ethically conscious German flower consumers consider the ethical acceptability of a flower product based on a reflection on production practices and the ethical issues associated with the flower product.

\section{Managerial Implications}

The previously discussed findings are of relevance to several actors in the horticultural industry including growers, flower retailers, and marketing managers. Marketing managers may want to consider the findings related to consumer concerns and adjust marketing strategies for fair trade cut flowers towards the ideals, aspirations, and aesthetics of ethical consumers and ensure that the flowers fit with their lifestyle. This may be accomplished by highlighting the labor and environmental aspects targeted by the Fair trade-certification scheme.

Given that concern for floricultural workers' treatment seems to drive the level of importance consumers place on fair trade as a cut flower attribute, marketing campaigns can emphasize the human rights aspects of fair trade cut flowers with emotive descriptors such as "roses without thorns" or "no blood flowers," highlighting this attribute and increasing their appeal to ethical consumers [37]. In the current pandemic environment, there is evidence that COVID-19 has heightened consumer awareness of ethical practices and products, and businesses should emphasize such practices to attract and retain consumers who actively seek this kind of information [74].

Growers and floral retailers could also capitalize on the findings of information practices and familiarity and provide consumer education to convince inexperienced or undecided consumers that fair trade flowers are a suitable product for them. Inexperienced flower consumers have been found to have a wide acceptability range [69] and are likely to use price as an indicator to determine flower quality [45]. However, such a strategy must be supported by evidence, demonstrating the authenticity and high quality of the product. This is necessary because during the COVID pandemic, consumers of "short living" horticultural products tend to prefer familiar products and may only choose expensive, innovative or sustainable alternatives if there is compelling and strong evidence, and if their budget permits [75]. These tendencies are also impacted by habits and social norms [74,75].

On the basis of these trends, certification and the societal impact of ethical flowers may provide justification for any price premiums of fair trade cut flowers. Quick response codes and apps proving authenticity, transparency and insights in floricultural chains and production conditions may be the means to realize this. These measures may also be appropriate for familiar buyers, as this affirms their values, their thinking on ethical acceptability, and clarifies the added value of the product. In a pandemic world, this feature to prove authenticity is more important than ever before, as shopping has dramatically shifted to online options $[74,75]$. In particular, price premiums from global value chains such as Fair trade flowers require increased transparency and evidence of certification to comply with pandemic guidelines, which are likely to remain in place as the "new normal" for future consumers [74]. Marketers need to remain conscious of these consumer requirements, especially during COVID, since the path to enhanced ethical consumption 
could be described as a rocky road. Economic insecurities and hardships resulting from COVID-19 in Germany are well documented [75].

\section{Limitations and Future Research}

The data for the present study are from 2016, and the significant changes in buying behaviors since that time, largely resulting from COVID-19 disruptions, need to be acknowledged. These changes, as well as the resulting trends, have not reversed in recent times, rather they are expected to become more permanent $[74,75]$ and these projections been outlined in the managerial implication. Further, the suggestions for future research also acknowledge these changes and future trends. Given that this study focuses on key factors determining fair trade buying behavior, which have not been widely explored, especially for the specific preferences for cut flower products and attributes or willingness to pay for floral products in Germany [5,6,33-36], this study still deliver value to the current body of literature.

A further limitation is that the sample was derived from an opt-panel provider. Optpanels are a standard method for data collection and may gain even more importance due to COVID-19. The limitation is that respondents working for opt-panel providers self-select into studies, and this might produce a biased sample, to the extent that these samples do not resemble the target population. Screening respondents according to quotas for demographic groups following the most recent census statistics has been employed and hopefully these measures help to make the sample sufficiently representative.

In future research, the question of what is perceived as fair by German consumers could be addressed. Given the occurrence of consumer confusion and the presence of various flower certification schemes addressing the concept of fairness, a willingness to pay scenario involving these certification schemes is worth exploring. This kind of study can answer the question of whether ethically conscious consumers prefer to support production in their own country or CoOs with poor environmental and labor reputations. This question is highly relevant for ethically conscious consumers, who have preferences for local, known, and transparent businesses providing authentic products. The focus of future investigations should highlight the impact of COVID-19, as the effects of the pandemic on relevant businesses and products that are important for these increasingly connected consumers. Such a comparative study is likely to be of high industry interest, as floricultural production and retail have been negatively affected by lockdowns and alert level changes in Germany and across Europe due to COVID-19.

Another direction studies could take is to examine consumer involvement, skills development, and the therapeutic benefits of growing flowers. This could involve doit-yourself (DIY) activities, floral production education and wellbeing, promoting plants and flowers as hobbies to help overcome the stress and isolation of prolonged periods at home during lockdowns. Likely consumer groups of interest would be middle class, as their lifestyle was most impacted by the pandemic [74] and they naturally have more reservations towards purchases [75]. Flower knowledge and propagation activities fit well in the growing trends of sharing, renting, DIY, and borrowing [74].

Floral gift giving could be explored. Being infected with COVID-19 can lead to sickness, hospitalization and death. Sympathy scenarios and floral gift giving are widely unexplored [35]. For these situations, the trend towards more long-lasting consumer goods such as potted plants may also be appropriate [33,75].

Lastly, future flower studies could also address floral preferences across generational cohorts including "Boomers," "Millennials" and "Generation Z" [57], as the latter two cohorts have a keen interest and higher willingness to pay for ethical products. Longitudinal flower studies should also consider the upcoming generation "Alpha" as future consumers, even though this bears extra challenges in research design and ethics, as this group will be considered as minors for the next 7 years. However, "Alphas" may hold similar values as their parents and are likely to be brought up through a millennial lifestyle. 
Author Contributions: Conceptualization, M.R. and D.L.D.; methodology, D.L.D.; validation, M.R., D.L.D., N.J.O.W. and V.B.; formal analysis, D.L.D.; investigation, M.R., N.J.O.W. and V.B.; resources, M.R., V.B., D.L.D. and N.J.O.W.; data curation, D.L.D.; writing-original draft preparation, M.R. and D.L.D.; writing一review and editing, D.L.D., N.J.O.W., V.B. and M.R.; visualization, D.L.D.; project administration, M.R.; V.B. and N.J.O.W. All authors have read and agreed to the published version of the manuscript.

Funding: No specific funding has been attributed to the project.

Institutional Review Board Statement: The study was conducted in accordance with the Declaration of Helsinki, and the protocol was approved by IRB at Purdue University in 2016 (Protocol number: 1512016849).

Informed Consent Statement: Informed consent was obtained from all subjects involved in the study.

Data Availability Statement: The data is available upon request from the corresponding author.

Acknowledgments: The authors wish to express their gratitude to Luke W. Tepid for his refreshing advice on the topic matter.

Conflicts of Interest: The authors declare no conflict of interest in the context of this publication. The funders had no role in the design of the study; in the collection, analyses, or interpretation of data; in the writing of the manuscript or in the decision to publish the results.

\section{References}

1. Langen, N. Are ethical consumption and charitable giving substitutes or not? Insights into consumers' coffee choice. Food Qual. Prefer. 2011, 22, 412-421. [CrossRef]

2. Otter, V.; Prechtel, B.; Theuvsen, L. Country of origin effect for food products from developing and transition countries: A PLS analysis of German consumers' perception. J. Int. Food Agribus. Mark. 2018, 30, 355-381. [CrossRef]

3. Sporleder, E.M.; Kayser, M.; Friedrich, N.; Theuvsen, L. Consumer preferences for sustainably produced bananas: A discrete choice experiment. Int. Food Agribus. Manag. Rev. 2014, 17, 59-82.

4. Andorfer, V.A.; Liebe, U. Research on fair trade consumption-A review. J. Bus. Ethics 2012, 106, 415-435. [CrossRef]

5. Rombach, M.; Widmar, N.O.; Byrd, E.; Bitsch, V. Do all roses smell equally sweet? Willingness to pay for flower attributes in specialized retail settings by German consumers. J. Retail. Consum. Serv. 2018, 40, 91-99. [CrossRef]

6. Berki-Kiss, D.; Menrad, K. Consumer preferences of sustainability labeled cut roses in Germany. Sustainability 2019, 11, 3358. [CrossRef]

7. Schouteten, J.J.; Gellynck, X.; Slabbinck, H. Do Fair Trade Labels Bias Consumers' Perceptions of Food Products? A Comparison Between a Central Location Test and Home-Use Test. Sustainability 2021, 13, 1384. [CrossRef]

8. Maaya, L.; Meulders, M.; Surmont, N.; Vandebroek, M. Effect of environmental and altruistic attitudes on willingness-to-pay for organic and fair trade coffee in Flanders. Sustainability 2018, 10, 4496. [CrossRef]

9. Ju, N.; Lee, K.H.; Kim, S.H. Factors Affecting Consumer Awareness and the Purchase of Eco-Friendly Vehicles: A Textual Analysis in Korea. Sustainability 2021, 13, 5566. [CrossRef]

10. Pyk, F.; Abu Hatab, A. Fairtrade and sustainability: Motivations for fairtrade certification among smallholder coffee growers in Tanzania. Sustainability 2018, 10, 1551. [CrossRef]

11. MacGregor, F.; Ramasar, V.; Nicholas, K.A. Problems with firm-led voluntary sustainability schemes: The case of direct trade coffee. Sustainability 2017, 9, 651. [CrossRef]

12. Shaw, D.; Grehan, E.; Shiu, E.; Hassan, L.; Thomson, J. An exploration of values in ethical consumer decision making. J. Consum. Behav. Int. Res. Rev. 2005, 4, 185-200. [CrossRef]

13. Carrington, M.; Chatzidakis, A.; Goworek, H.; Shaw, D. Consumption ethics: A review and analysis of future directions for interdisciplinary research. J. Bus. Ethics 2021, 168, 215-238. [CrossRef]

14. Zollo, L. The consumers' emotional dog learns to persuade its rational tail: Toward a social intuitionist framework of ethical consumption. J. Bus. Ethics 2021, 168, 295-313. [CrossRef]

15. Harrison, R.; Newholm, T.; Shaw, D. (Eds.) The Ethical Consumer; SAGE Publications: Thousand Oaks, CA, USA, 2005.

16. Morgan, C.J.; Croney, C.C.; Widmar, N.J. Exploring relationships between ethical consumption, lifestyle choices, and social responsibility. Adv. Appl. Sociol. 2015, 6, 199-216. [CrossRef]

17. Tomșa, M.M.; Romonți-Maniu, A.I.; Scridon, M.A. Is Sustainable Consumption Translated into Ethical Consumer Behavior? Sustainability 2021, 13, 3466. [CrossRef]

18. BMEL. Performance Report Horticulture and Viticulture [Ertragslage Gartenbau und Weinbau]. 2021. Available online: https:// www.bmel-statistik.de/landwirtschaft/gartenbau/veroeffentlichungen-zum-gartenbau/ertragslage-garten-und-weinbau/ (accessed on 4 September 2021). (In German)

19. Zentralverbandes Gartenbau e. V. (ZVG). Annual Report. [Jahresbericht]. 2020. Available online: https://www.g-net.de/zvgjahresbericht.html (accessed on 4 September 2021). (In German) 
20. Buschman, J.C.M. Globalization-Flower-Flower bulbs-Bulb flowers. Acta Horticurae 2005, 673, 27-33. [CrossRef]

21. UN Comtrade. Flowers Cut Flowers and Flower Buds Suitable for Bouquets and Any Kind of Ornamental Purposes. 2018. Available online: https: / comtrade.un.org/data (accessed on 6 October 2021).

22. Tizazu, T.Y.; Workie, M.A. Social, economical and environmental issues of floriculture sector development in Ethiopia. Rev. Plant Stud. 2018, 5, 1-10. [CrossRef]

23. Riisgaard, L.; Hammer, N. Prospects for labor in global value chains: Labor standards in the cut flower and banana industries. Br. J. Ind. Relat. 2011, 49, 168-190. [CrossRef]

24. Riisgaard, L. Global value chains, labor organization and private social standards: Lessons from East African cut flower industries. World Dev. 2009, 37, 326-340. [CrossRef]

25. Kuiper, G.; Greiner, C. Export horticulture and labour migration in Kenya: Translocality and transiency in a secondary town. Geoforum 2021, 122, 1-10. [CrossRef]

26. Gobie, W. A seminar review on impact of floriculture industries in Ethiopia. Int. J. Agric. Econ. 2019, 4, 216-224. [CrossRef]

27. Mekonnen, M.M.; Hoekstra, A.Y.; Becht, R. Mitigating the water footprint of export cut flowers from the Lake Naivasha Basin, Kenya. Water Resour. Manag. 2012, 26, 3725-3742. [CrossRef]

28. Hanssen, V.M.; Nigatu, A.W.; Zeleke, Z.K.; Moen, B.E.; Bråtveit, M. High prevalence of respiratory and dermal symptoms among Ethiopian flower farm workers. Arch. Environ. Occup. Health 2015, 70, 204-213. [CrossRef]

29. Friedman, E.; Hazlehurst, M.F.; Loftus, C.; Karr, C.; McDonald, K.N.; Suarez-Lopez, J.R. Residential proximity to greenhouse agriculture and neurobehavioral performance in Ecuadorian children. Int. J. Hyg. Environ. Health 2020, 223, 220-227. [CrossRef] [PubMed]

30. Pereira, P.C.; Parente, C.E.; Carvalho, G.O.; Torres, J.P.; Meire, R.O.; Dorneles, P.R.; Malm, O. A review on pesticides in flower production: A push to reduce human exposure and environmental contamination. Environ. Pollut. 2021, 289, 117817. [CrossRef] [PubMed]

31. Statista. Turnover for Fairtrade Cut Flowers in Germany from 2011 to 2020. 2020. Available online: https://de.statista.com/ statistik/daten/studie/171405/umfrage/absatz-von-blumen-mit-fairtrade-siegel-seit-2005/ (accessed on 4 September 2021).

32. Statista. Turnover for Fairtrade Cut Flowers Stems in Germany. 2020. Available online: https://de.statista.com/statistik/daten/ studie/299495/umfrage/umsatz-mit-fairtrade-blumen-in-deutschland/\#statisticContainer (accessed on 4 September 2021).

33. Klaehre, D.P.; Kaim, E.; Heller, J. Ethical Consumption of ornamental plants. An analysis of preferences for consumer labels. [Ethischer Konsum bei Zierpflanzen-Eine Präferenzanalyse mit Verbraucherlabels]. In DGG-Proceedings; Deutsche Gartenbauwissenschaftliche Gesellschaft (DGG): Osnabrueck, Gerrmany, 2017; pp. 1-5. (In German) [CrossRef]

34. Berki-Kiss, D.; Lampert, P.; Menrad, K. Fairtrade or conventional roses-Influencing factors for sustainability conscious consumer choice. In DGG-Proceedings; Deutsche Gartenbauwissenschaftliche Gesellschaft (DGG): Geisenheim, Gerrmany, 2018; pp. 1-5. [CrossRef]

35. Rombach, M.; Dean, D.L.; Olynk Widmar, N.J.; Bitsch, V. “Oh, You Shouldn't Have!” Understanding Key Factors Impacting Cut Flowers Gifting Preferences in Germany. Horticulturae 2021, 7, 368. [CrossRef]

36. Rombach, M.; Bitsch, V. A typology of online flower shops on the German market. Acta Hortic. 2016, 1132, 127-134. [CrossRef]

37. Singh, P. No roses without thorns: Global consumers of cut flowers as political actors. Ky. J. Equine Agric. Nat. Resour. Law 2013, 6, 23-58.

38. Werren, J. Country of Origin Labelling and Purchasing Cut Flowers in Australia: What Are the Social and Moral Considerations for Consumers. AJEL 2015, 2, 77-102.

39. Holt, D.; Watson, A. Exploring the dilemma of local sourcing versus international development-The case of the flower industry. Bus. Strategy Environ. 2008, 17, 318-329. [CrossRef]

40. Ambrožová, M.; Částek, O. Purchasing behavior of Fairtrade customers. Acta Univ. Agric. Silvic. Mendel. Brun. 2013, 61, 1957-1967. [CrossRef]

41. Gross, S.; Roosen, J. Effects of information on social trust in farmers regarding animal welfare. Int. Food Agribus. Manag. Rev. 2021, 24, 121-137. [CrossRef]

42. Frewer, L.J.; Koles, A.; Van De Kroon, S.; Lawere, C. Consumer acceptance of animal husbandry systems. J. Agric. Environ. Ethics 2005, 18, 345-367. [CrossRef]

43. McKendree, M.G.; Croney, C.C.; Widmar, N.O. Effects of demographic factors and information sources on United States consumer perceptions of animal welfare. J. Anim. Sci. 2014, 92, 3161-3173. [CrossRef]

44. De Pelsmacker, P.; Driesen, L.; Rayp, G. Do consumers care about ethics? Willingness to pay for fair-trade coffee. J. Consum. Aff. 2005, 39, 363-385. [CrossRef]

45. Strong, C. The problems of translating fair trade principles into consumer purchase behaviour. Mark. Intell. Plan. 1997, 15, 32-37. [CrossRef]

46. Aksoy, H.; Ozsonmez, C. How millennials' knowledge, trust, and product involvement affect the willingness to pay a premium price for Fairtrade products. Asian J. Bus. Res. 2019, 9, 95-112. [CrossRef]

47. Howard, P.H.; Jaffee, D. Tensions between firm size and sustainability goals: Fair trade coffee in the United States. Sustainability 2013, 5, 72-89. [CrossRef]

48. Liu, C.C.; Chen, C.W.; Chen, H.S. Measuring consumer preferences and willingness to pay for coffee certification labels in Taiwan. Sustainability 2019, 11, 1297. [CrossRef] 
49. Maciejewski, G.; Mokrysz, S.; Wróblewski, Ł. Segmentation of coffee consumers using sustainable values: Cluster analysis on the Polish coffee market. Sustainability 2019, 11, 613. [CrossRef]

50. Birkenberg, A.; Narjes, M.E.; Weinmann, B.; Birner, R. The potential of carbon neutral labeling to engage coffee consumers in climate change mitigation. J. Clean. Prod. 2021, 278, 123621. [CrossRef]

51. Torma, G.; Thøgersen, J. A Systematic Literature Review on Meta Sustainability Labeling-What Do We (not) Know? J. Clean. Prod. 2021, 293, 126194. [CrossRef]

52. Moon, S.J.; Costello, J.P.; Koo, D.M. The impact of consumer confusion from eco-labels on negative WOM, distrust, and dissatisfaction. Int. J. Advert. 2017, 36, 246-271. [CrossRef]

53. Rombach, M.; Widmar, N.; Byrd, E.; Bitsch, V. Understanding preferences of German flower consumers: The desire for sustained beauty. Int. J. Retail Distrib. Manag. 2018, 45, 560-576. [CrossRef]

54. Kempkens, K.; Billmann, B. Production and market of organic ornamentals. A workshop with experts. In Proceedings of the Expertenworkshop Oekologischer Zierpflanzenbau, Landwirtschaftskammer Nordrhein-Westfalen, Köln-Auweiler, Cologne, Germany, 2009. (In German)

55. Nelson, V.; Tallontire, A. Battlefields of ideas: Changing narratives and power dynamics in private standards in global agricultural value chains. Agric. Hum. Values 2014, 31, 481-497. [CrossRef]

56. Cummins, A.M.; Widmar, N.J.O.; Croney, C.C.; Fulton, J.R. Understanding consumer pork attribute preferences. Theor. Econ. Lett. 2016, 6, 166. [CrossRef]

57. Rihn, A.L.; Yue, C.; Behe, B.; Hall, C. Generations X and Y attitudes toward fresh flowers as gifts: Implications for the floral industry. HortScience 2011, 46, 736-743. [CrossRef]

58. Auger, P.; Deveinney, T.M.; Louviere, J.J. Using best-worst scaling methodology to investigate consumer ethical beliefs across countries. J. Bus. Ethics 2007, 70, 299-326. [CrossRef]

59. Paetz, F.; Guhl, D. Understanding differences in segment-specific willingness-to-pay for the fair trade label. Mark. ZFP-J. Res. Manag. 2017, 39, 37-46. [CrossRef]

60. Paetz, F. Analyzing socio-demographic determinants for fair trade label's price premia: A practical approach. Arch. Data Sci. 2020, 7, 1-19. [CrossRef]

61. Pedrini, M.; Ferri, L.M. Socio-demographical antecedents of responsible consumerism propensity. International. J. Consum. Stud. 2014, 38, 127-138. [CrossRef]

62. Michaud, C.; Llerena, D.; Joly, I. Willingness to pay for environmental attributes of non-food agricultural products: A real choice experiment. Eur. Rev. Agric. Econ. 2013, 40, 313-329. [CrossRef]

63. German Census. Census Data Base of the Census. 2011. Available online: https://ergebnisse.zensus2011.de/?locale=e (accessed on 29 September 2021).

64. Gefen, D.; Straub, D.W.; Boudreau, M. Structural equation modeling and regression: Guidelines for research practice. Commun. Assoc. Inf. Syst. 2000, 4, 1-77. [CrossRef]

65. Hair, J.F.; Hult, G.T.M.; Ringle, C.M.; Sarstedt, M. A Primer on Partial least Squares Structural Equation Modeling (PLS-SEM); SAGE Publications: Thousand Oaks, CA, USA, 2017.

66. Wold, H. Nonlinear iterative partial least squares (NIPALS) modeling: Some current developments. In Multivariate Analysis III, Proceedings of the Third International Symposium on Multivariate Analysis Held at Wright State University, Dayton, OH, USA, 19-24 June 1972; Krishnaiah, P.R., Ed.; Academic Press: New York, NY, USA, 1973.

67. Hair, J.F.; Ringle, C.M.; Sarstedt, M. PLS-SEM: Indeed, a silver bullet. J. Mark. Theory Pract. 2011, 19, 139-152. [CrossRef]

68. Fornell, C.; Larcker, D.F. Evaluating Structural Equation Models with Unobservable Variables and Measurement Error. J. Mark. Res. 1981, 18, 39-50. [CrossRef]

69. Henseler, J.; Ringle, C.M.; Sarstedt, M. A new criterion for assessing discriminant validity in variance-based structural equation modeling. J. Acad. Mark. Sci. 2015, 43, 115-135. [CrossRef]

70. Schettler, C.; Rombach, M.; Bitsch, V. Perceived advantages and barriers of buying cut flowers online. Acta Hortic. 2016, 1132, 9-16. [CrossRef]

71. Schreiner, M.; Korn, M.; Stenger, M.; Holzgreve, L.; Altmann, M. Current understanding and use of quality characteristics of horticulture products. Sci. Hortic. 2013, 163, 63-69. [CrossRef]

72. Behe, B.K.; Wolnick, D.J. Type of floral product purchased and demographic characteristics and floral knowledge of consumers. HortScience 1991, 26, 414-416. [CrossRef]

73. Manohar, S.; Rehman, V.; Sivakumaran, B. Role of unfamiliarity and information on consumers' willingness to try new healthy foods. Food Qual. Prefer. 2021, 87. [CrossRef]

74. Hoekstra, J.C.; Leeflang, P.S. Marketing in the era of COVID-19. Ital. J. Mark. 2020, 4, 249-260. [CrossRef]

75. Menrad, K. Sustainability in the light of the Corona-Crisis [Nachhaltigkeit und Konsum im Lichte der Corona-Krise]. In Food for thought for the Time after Covid-19 [Denkanstöße für die Zeit nach Corona. TUM Forum Sustainability-Wissenschaft, Vernunft E Nachhaltigkeit]; Molls, M., Ed.; Eberspächer: München, Germany, 2020; pp. 182-185. (In German) 